\title{
Study Technology: The Suitable Tenacity to Learning Snags
}

\section{Amos Ochayi ONOJAH ${ }^{*}$, Adenike Aderogba ONOJAH ${ }^{2}$, Charles Olubode OLUMORIN $^{3}$, Isaac Olakanmi ABIMBOLA4}

\author{
1,2,3 Department of Educational Technology, Faculty of Education, University of Ilorin, Ilorin, Nigeria \\ ${ }^{4}$ Department of Science Education, Faculty of Education, University of Ilorin, Ilorin, Nigeria \\ e-mail: haymoresonojah@yahoo.comtemiladeadenike2015@yahoo.com, bodeolumorin22@unilorin.edu.ng,
} abimbola.io@unilorin.edu.ng

\begin{abstract}
Study technology is a student-centered learning technique that helps the learner to study successfully by providing solutions to all barricades come upon in the progression of studying. This study designed a model on study technology with the barriers that hinder students from studying effectively, the psychological reactions as well as the solutions to the barriers. The study is a position paper which directs the author to review some materials. The findings established that the major barriers to successful study are absence of mass, misunderstood words, obscurity and skipping gradient. In addition, the proffered solutions to the barriers include use of learning materials, use of dictionary, applying mnemonics and adopting a systematic learning style. The study concluded that with study technology, 100\% performance is achievable. It was however recommended that students at all levels should assist themselves by adopting the study technology principles.
\end{abstract}

Keywords: Study Technology, Tenacity, Snags, Learning, Mnemonics.

\section{Introduction}

No society grows as expected without investing in their education system. A territorial army of sheep commanded by a lion could overthrow a militia of lion controlled by a sheep, this depict the need to value education. However, if education will be valued, the effective utilization of means to boost such education is inevitable. Every graduate is expected is expected to have marvellous impact on their respective society, Nation and word at large after they have completed their studies in schools. Although, (Ajayi, K. \& Ogunyemi, 1990) stated that school variables, personality factors, socio-economic variables among others had made the expected result of graduates to be on the decline since the middle 1980s. These factors if not properly taken care of could jeopardize learning and improve drastically in the performance weakening. These factors gradually deteriorate students understanding of a concept. Education is a social medium and process of attainment of pertinent acquaintance, skills and attitudes for subsistence in a fluctuating world (Sanni et al., 2017).

However, there are several factors which could affect students learning. These factors hinder most students from achieving their intended goal thereby affecting performance. The three prime barriers that prevents one from magnificently learning (Hubbard, 1972). These three barriers cannot be isolated as paramount to effective education. These barriers could lead to poorly educated students, unfulfilled potential and frustration for students in their learning (Applied Scholastic International, ASI, 2019). Study technology is a student-centred learning technique that helps the learner to study successfully by providing solutions to all barriers encountered in the process of studying. Study Technology is a feasible methodology which makes it conceivable for a person to identify and lever the barriers to successful study. ICT is the use of scientific tools and techniques for developing, detailing and communicating information for resolving complications or providing desirable amenities in numerous zones of human exertion (Soetan et al., 2020).

\footnotetext{
${ }^{*}$ Corresponding author.

Received 03 June 2020; Accepted 23 August 2020; Available online 01 September 2020 (c) 2020 JPI. All Rights Reserved
} 
There is no teaching method that is the best nor is there any technology adopted to facilitate learning that should be regarded as the best. Learning situation or context determines the method and technology that best suits any learning. Studies on objectives and nature of research showed that research is the systematic and objective process of finding solution to the problems (Bako, 2020). Each of the method is best to a particular learning experiences, while the lecture method might be appropriate when learners are much and the task is to be completed within a short or limited time, E-learning is appropriate only when power source is guaranteed, Online learning is appropriate when bandwidth is available at both ends (teacher and learner). Assistive technology like braille which is appropriate for the visually challenged, the same braille is of no use to the hearing challenged.

Snags as used in this study refers to challenges, difficulties and can be regarded as those things that prevent advancement or attainment of any clear aim. Thus, snags refer to those things that hinders students from achieving a successful study. Slow unavailability of time, lack of awareness of resources, information overload, inaccessibility to important resources, were the barriers to towards the use of some resources for learning (Lavanya \& Santharooban, 2018). The right word to be used in learning situations is "Appropriate" and "not Best" i.e. appropriate method or appropriate technology. Snags as used in this study refers to learning difficulties, these difficulties are the barriers which hinders learners from studying effectively. Moreover, academic research conduces to be systematic, methodical and comprehensible gain in new knowledge. This knowledge helps to prevent, solve or to control current and future problems (Fritzenschaft, 2014).

The solitary responsibility of the student is for them to study and guarantee academic success, hence countless scholars advance learning conducts or practices that would enhance their academic quest (Onuoha \& Subair, 2013). Research conducted by (Onojah et al., 2019) stated that undergraduate students are prepared to adopt study technology for learning and the variance between male and female undergraduate students' readiness towards the adoption of study technology for learning was not found to be significant. There are series of difficulties which the students faced while trying to acquire knowledge or learn a concept or training, these problems vary per students as each learner have what seems to jeopardize their learning activities. Most previous studies had focused on technologies that could be adopted in curbing these barriers but most times it does not generally work on every student. This could be grounded on the fact that no technology is an island of problem solving. Thus, there is a need to have a strategy which permits each learner to tackle the difficulty encountered in the process of erudition. With this, every learner can learn successfully by discovering their learning swags and as well proffer resolutions founded on each barrier faced at each stage of the learning process. This is the reason for this study.

The major determination of the study is to prepare a position paper on the barriers to effective study. Specifically, the study; investigate the barriers that hinder students from studying effectively; assessed the psychological reactions learners encounter when engaged in the barriers issue; determine the appropriate solutions to the barriers to successful study; and design a model on Study technology.

\section{Method}

This is a position paper. It employed the design method approach. This method was adopted because the article designed a model for successful study. The model are in phases comprising the barriers to study, the psychological reactions on each of the problems, as well as the soultions to each problems. According to Hubbard, three study problems were discovered but the authors of this article added one extra barrier to become four. They as well reveal the psychology reactions encountered by students when they encounter any of the barriers. The study is a position paper which directs the author to review some materials, find out some problems and thus proffer apt solutions to the identified problem. The instrument was validated by Eights experts from the Department of Educational Technology, Department of Sciences and department of computer science across universities in Nigeria for face and content validity so as to ensure the instrument remains valid and capture what it really ought to capture in line with the stated objectives. Their observations and corrections were used to 
modify the instrument and perfected the model designed in this manuscript to ensure students learn effectively.

\section{Results and Discussion}

The three barriers to successful study as noted by (Hubbard, 1972) are discussed. The three barriers are absence of mass, misunderstood word and Skipped gradient. However, another major barrier added in this study is obscurity. Thus, the barriers to successful study are now four. These factors will be discussed accordingly.

\section{Lack of Mass}

The first barrier which is the Lack of mass simply refer to endeavouring to educate someone lacking the mass (or object) that he is going to be involved with. This can make study exceedingly difficult. This is a situation whereby the learning process is done in an abstract situation, that is without the materials that can be used to describe the lesson by modification or real material. This is the first barrier to study as stated by (Church of Scientology international, 2019) is for instance, studying about tractors, the in-print page and the verbal word are no supernumerary for a concrete tractor. Deficient a tractor to sub with the printed word, or at slightest images of a tractor, can close off a person's understanding of the subject. Learning is permanently registered in the brain when it is accompanied by the real time situations. This could be the real object or the modified instructional media or materials. Research conducted by (Olumorin, 2009) established through his study that instructional materials are achievable either by production of new ones or modification of existing ones. Learning is better inscribed in the brain just like inscription on a stone which could last forever. This is only achievable when the material that depicts such concept is made available to the learners. The availability and accessibility of a real or virtual image to corroborate learning concept will in one way influence the learning achievement and comprehension of a concept, thus there is need to make learning more concrete as the learning will be engraved permanently on the brain of the individual learners for easy recall.

Empirical studies of (Mathew et al., 2015) conducted on the role of information and communication technology in Nigerian educational system; and (Ajegbelen, 2016) who investigated the use of ICT to enhance university education in Nigeria revealed via their studies that unstable electric, poor internet connectivity, download of irrelevant information, time factor from the lecturers are some of the barriers to the use of search engines. But this may differ with study technology techniques. Certain functional rejoinders emanate after trying to instruct a person in a subject without the realia actually present or available cruis (Ndong, 2007). Students who come across this barrier will have a habit of to feel squashed, bent, sort of spiny, sort of dead, bored and exasperated. Such individuals can gust up with his expression of feeling dense, with headaches, and with his stomach sensation funny. He can also feel woozy from period to stretch and eyes hurting often. Research conducted by (Oladipo et al., 2010) noted that these reactions which emanate from this learning barrier are quite mutual but mistakenly accredited to poor illumination, or studying too late at night, or any number of other incorrect reasons. However, the actual basis is a non-existence of figure or physique on the topic or subject one is learning. The remedy to this barrier is to supply the material of the concept itself. The tractor, or a reasonable substitute should be made available.

Some instructors have intuitively known this, but frequently it was functional only to younger students and it definitely was never given the reputation its authorisations at any level of education (Applied Scholastic International, 2019). Resources for learning should be made available as both learning contents as well as materials to boost learning activities. ICT tools expand the range of choices and opportunities by facilitating greater access to students' educational development, opens up equal opportunities to students and teachers as well as help to level the field by increasing the students' participation in economic and human envelopment activities (Amesi \& Yellowe, 2018). The adoption of ICT into the learning activities can makes learning faster, safer, interesting and permanently inscribed. The available indigenous instructional resources are being utilized by basic technology teachers and there was no significant difference between male and female teacher utilization of indigenous 
instructional resources for teaching basic technology (Soetan et al., 2020). This implies that in the case where the factory furnished are expensive to procure, the indigenous ones which could even be extracts from waste could be garnished to form an attractive learning resources with the assistance of a creative tutor. What learners see with their sight can go along way achieving what they hear only in multiple folds.

\section{Too Steep a Gradient}

The second barrier is too steep a gradient. The too-steep a study gradient occurs when student(s) is enforced into tasking a new achievement without partaking understanding of the preceding action. This brings a confusion result. There exist a diverse set of these physiological rejoinders which transpire from consequence of this barrier. The use of ICT encourages cooperative learning, enhances teaching and learning process, and encourages communication through websites, blogs and social networks (Augustine et al., 2018). Just like skipping a step in a ladder when climbing which could lead to an accident in the process, so are students likely to have an accidental brain or accidental intellectual damage during the learning procedures. When one hits too steep a gradient, a sort of confusion or realigns (moving or swaying like one might fall) is experienced. At any time when learners try to ignore any learning process, the next stage will be affected which could in turn affect the learning outcome at the latter end. Commonly, the difficulty is ascribed to the new action, when in fact it really stems from the previous action (Church of Scientology international, 2019). This is because the person did not fully understand some part earlier and then went into confusion on the new one. There are some topics that are prerequisite of another topics and if learning is not achieved in the previous stage, learning may not occur or difficult to occur in the new topics to be introduced by the teacher or learner themselves.

In the modern world of information in many forms around the human each day, use of learning facilities turn out to be an essential part of information atmosphere and they are substituting the role of libraries in smoothing information repossession and entree (Ajegbelen, 2016). There are checklists both manually and automated or electronic which could be used to track the extent of previous achievement in learning before proceeding to another next or higher stage. However, if any of the processes is skipped, the expected learning outcome may not be efficiently achievable. Just like the entry behavior of learner could affect the new lesson, thus each preceding learning module affect the next lesson when the latter is skipped. The entering behavior in the lesson plan is designed to cater for this by knowing if learners achieved what they learnt in the preceding lesson. This difficulty is commonly accredited to the new action, when in fact it actually shoots from the previous action of which the individual did not fully comprehend some part earlier and thus moved into muddle on the new one (Church of Scientology international, 2019). He who fights and run away live to fight another day, correspondingly learners who abandon a particular concept that was not appropriately comprehended will leave to struggle with the lesson another time.

Research as a process is often conducted in steps, so learning also require some scientific procedures (Owolabi, 2016). A unit progress to cell, cell progress to tissue and tissue progress to system but if any of the progression is missed will result in the non-achievement of the desired outcome. The practical experience or experimental activity usually requires some stages that must not be skipped to accomplish the objectives, aim or goal for which the learning is intended for. For instance, a person learning to drive engaged in properly coordinating feet and hands simultaneously to manually swing the car into alternative gear while keeping to one lane is procedural. The struggle will be originated to lie in around earlier action about shifting gears. Perhaps he was not hitherto contented with shifting through the gears while the engine is off and the car also at rest. When, this is known, the rise can be cut back, and the soul took up to a point where he can simply shift the gears on a stationary car before execution the similar accomplishment while in gesticulation (Hubbard, 1972). The remedy to this is too follow the process gradually without skipping any step. Steps are encouraged to be followed accordingly without jumping over any in other to arrive well because fulfilled process results in fulfilled output. Thus, skipped process also yield half-baked learning outcome. 
Processing and distributing of information require combining skills and procedure. This technology can be used to offer projected outcomes with slight flaw or flawless, stable, consistent and interactivity in learning (Sanni et al., 2017). For every stated plan on any particular budget, the procedures should be accordingly tracked and pursued. Learner should be encouraged and advised to proceed in their learning activities without prancing any of the stage in other to overcome the problems arising from not perfecting the previous activities before proceeding to the innovative one. ICT help students toil collaboratively and advance higher-order intelligent skills, inspire students to be involved in the learning development but such processes should not be skipped (Arrosagaray et al., 2019; Fernández-Gutiérrez et al., 2020; Issa et al., 2017). One thing at a time is the reason why clock tick one at a time and nanoseconds accumulate to seconds, seconds aggravate to minute, minutes exacerbate to hour, hours intensify into day, days heighten to week, weeks amplify to month, months enhance into years, years amass to a lifetime. Thus, there cannot be a year without months and so learning may not be achieved if any stage is not peculiarly implemented to fulfillment.

\section{The Misunderstood Word}

The third barrier of the misunderstood word is the prime factor involved with stupidity and many other unwanted conditions (Olumorin, 2009). This occur from either ambiguous word or wrong interpretation. This barrier is synonyms to putting the wrong peg in the right hole or inserting the right peg in the wrong hoe. Whichever way, the wrong outcome will be achieved. ICT tools are technologies used for collecting, storing, editing and dissemination of information in various form (Issa et al., 2017). However, any misunderstood concept could destroy such learning outcomes. A misunderstood definition or a not-comprehended definition or an undefined word is capable of thoroughly block one's understanding of a subject and can even reason one to abandon the subject wholly (Applied Scholastic International, 2019). Different set of physical reactions might occur absolutely when a learner reads past words he does not understand well. These reactions make the learner look confused, stressed and confidently stupid thinking he/she is right.

Misunderstood word varies entailing a misunderstood definition or a not-comprehended definition or an undefined word can meticulously block one's understanding of a subject and can even lead to absolutely abandoning a subject. The sophistication of a concept is contingent on the degree of its enhancement for learning purposes (Abimbola, 2013). It does not only happen while reading, it exists also when a learner hears a word that is not well understood. Misunderstood word occurs when a student does not fully understand word(s) as used in a statement and might also be that the student misinterprets such word (Onojah et al., 2019). Going past a word or symbol for which one does not have a proper definition gives one a distinctly blank or washed-out feeling. It is a fact that no nation should or is expected to grow above the quality of its educational level and educated citizen. The major purpose of education is to assist individuals to maximize their potentials for most efficient self and national development (Gambari \& Yusuf, 2014). The person will get a "not there" feeling and will begin to feel a nervous or hysteria (Lake, 2003). These are manifestations distinct from either of the other two barriers.

Consider the conversation below between John and Serah,

Serah : what is your pen name? (i.e. his familiarity name)

John : Eleganza (name of a pen producing company but called by the pen)

Serah : Get me my tablet (i.e. Android phone)

John : Are you sick?

Serah : I beg your pardon

John : Please don't beg me

Most of Serah's statement were misunderstood by her brother John. There is a significant difference in the academic performance of university students in a course of study when study technology was used in place of lecture method (Newman, 2019). The misunderstood words have much to do with human relations, the mind and different subjects. It establishes aptitude or lack of aptitude and is the key to what psychologists were attempting to test for years without 
recognizing what it was. The remedy to this barrier is the use of dictionary. This dictionary could be in different form depending on its availability and accessibility.

A misunderstood word will remain misinterpreted until one clears the meaning of the word and once the word is fully understood by the person, it is said to be cleared. Steps to word clearing by (Church of Scientology international, 2019) in the scientology handbook are as follows: Firstly, have a dictionary to hand while reading so that you can clear any misunderstood word or symbol you come across as described in figure 1. A simple but good dictionary can be found that does not itself contain large words within the definitions of the words which themselves have to be cleared. Correspondingly, when you come across a word or symbol that you do not understand, look it up in a dictionary and look rapidly over the definitions to find the one which applies to the context in which the word was misunderstood. Read that definition and make up sentences using the word with that meaning until you have a clear concept of that meaning of the word. This could require ten or more sentences. Then clear each of the other definitions of that word, using each one in sentences until you clearly understand each definition. The next thing to do is to clear the derivation, which is the explanation of where the word came from originally. This will help you gain a basic understanding of the word. If there are idioms for the word to clear, they are cleared as well. Clear any other information given about the word, such as notes on its usage, synonyms, etc., so as to have a full understanding of the word. Moreover, if you encounter a misunderstood word or symbol in the definition of a word being cleared, you must clear it right away using this same procedure and then return to the definition you were clearing.

\section{Obscurity}

The fourth barrier is the 'obscure concept' which is the quality of concept or words being difficult to understand or memories. This is also the act of a concept being incomprehensible or vague. Whenever a learner tries to understand or study a concept with so many attributes, it becomes difficult. Therefore, such concepts could be abbreviated or use acronyms to represent such for easy recall. Globally, ICT has initiated a transition from analogue to digital operations in all aspects of human endeavour making it possible for a lot of activities to be carried out speedily, easily and accurately (Justina et al., 2018). But these could be uneasy when concept becomes difficult to comprehend. The remedy that if integrated can help a learner to study successfully and be obscure free are the use of the following mnemonics techniques aabbreviations: This is the shortening of long words e.g. Olorunnifesieminikansoso abbreviated to Knife; aacronyms: This is representing word(s) with the first letter. A good example of this is BODMAS, MR NIGERD, NUC, WAEC, GRACE (Gods Riches and Christ Experience) etc.; cues: An action or event that is a signal for an occurrence or another event e.g. Sound of thunder is a signal that rain might fall; rreminders: This is something that makes one remember what one might/have forgotten e.g. someone who had witnessed Lion attack before will remember this incidence if encountered with a picture of a lion or lion in a zoo. Also, in mastering Good, Better, Best. This can be composed as 'Better isn't Good enough, endeavor to be the Best'.

Study Technology are tools and techniques that can be employed to improve the students' learning rates. It includes the use of Physical objects like real objects, pictures, models or illustrations; Seeking dictionary for unfamiliar words; Going through a course material step-by-step; and the use of mnemonics which include the use of advanced organizers, use of abbreviations, Practice of Acronyms, Cues, Reminders, Games and Simulations to assist or intended to assist the memory. All these barriers and their psychological reactions alongside the remedies are displayed graphically in Figure 1. 


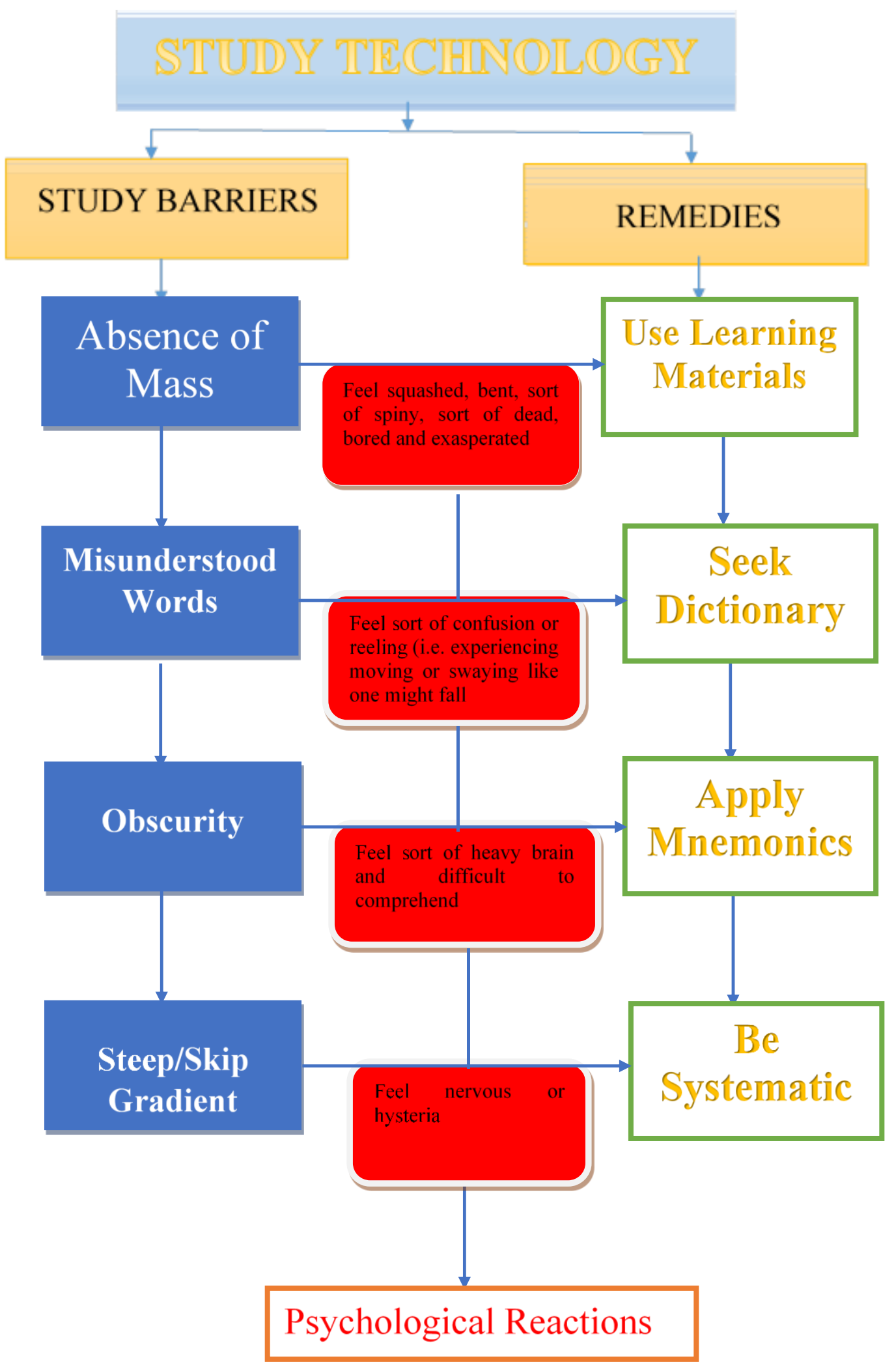

Figure 1: AMOS Model of Study Technology

Study technology as a widespread solution that is capable of curing all learning ill or the ills in educational institutions and larger society (Abimbola, 2011). The Study technology help students to truly understand what they study and essentially how to learn. It is simply learning how to learn. Even though those advocating study technology are not educators but 
their work can be traced to cognitive signs research tradition. Technology and education surely put are a series of tools that would possibly be imperative and vital in augmenting and improving students' learning. The instructors might also work in a broad range of settings with unique sorts of access to resources, each and every student deserves an instructor who can use on hand technological equipment to better meet student desires (King, 2016). The study technology concept will assist students and guide them through the learning activities for them to achieve a perfect study which is efficient and effective.

Educational technology is a systematic way of conceptualizing the whole learning process in terms of unique objectives and communication; and employing a combination of human and non-human resources to bring about more effective instruction (Alam, 2018). While some cognitive scientists' owed research from tradition to information processes technology, other researchers in cognitive science traced their theoretical based to philosophy of science. Creativity is clearly the potential to create options out of thin air. Education Technology, a revolution in the making. If properly integrated into the field of education, it could produce skills, knowledge, competencies, as well enhance the improvement of human potentials to promote technologic related learning (Okenjom et al., 2016).

Educational technology is a systematic way of conceptualizing the whole learning process in terms of unique objectives and communication; and employing a combination of human and non-human resources to bring about more effective instruction (Alam, 2018). While some cognitive scientists' owed research from tradition to information processes technology, other researchers in cognitive science traced their theoretical based to philosophy of science. Creativity is clearly the potential to create options out of thin air. Education Technology, a revolution in the making. If properly integrated into the field of education, it could produce skills, knowledge, competencies, as well enhance the improvement of human potentials to promote technologic related learning (Okenjom et al., 2016). Compared cognitive science and study technology and stated that out of 16 items, cognitive science and study technology have 11 in common (Abimbola, 2011). Therefore, it can be deduced that there is a strong relationship between cognitive science and study technology. Study technology is not a collection of study tips or memory tricks, but rather a system of learning how to learn. Study technology consists of tools and techniques that teachers can use to improve the learning rates of students and can be used by students themselves to improve their ability to understand and to use the materials they read and study, and it remains vital for continued learning (Applied Scholastic International, 2019). Cognitive science also has its root in both psychology (human beings construct their own memory) and philosophy (human beings are science themselves).

Study technology is not just another method of study, it also allows a learner to learn any subject successfully and it also empowers learners to achieve the goals they have set in life on what they want to be and what they want to do. Study technology is used by Scientologists as part of their training, and is also promoted outside the church by an affiliated corporation known as Applied Scholastics, which presents study technology as a secular, universally applicable method to enhance the comprehension of any student, studying any topic.

\section{Conclusion}

Learning situation or context determines the method and technology that is most appropriate to any learning. The components of study technology include the use of learning materials to illustrate the concept being taught; breaking down complex concepts into steps for easy mastering, applying cues for obscure concepts, and seeking the dictionary for unfamiliar words. These components can be used independently or jointly to achieve the desired result of successful studying thereby increasing performance. With study technology, $100 \%$ is possible since the concept of study technology is about learning it all, knowing it all, using it all and recalling it all. 


\section{Acknowledgements}

Our sincere appreciation goes to the sponsors of this journal and the editors who took their time to make this possible. We also appreciate the reviewers for their effort. Finally, we acknowledge all authors whose work were cited in this article.

\section{References}

Abimbola, I. O. (2011). Study technology: A new teaching and learning tool for higher education in Nigeria. In D. O. Durosaro, \& A. A. Adegoke. Higher Education and Globalization, 5969. Ibadan: Stirling-Hordan Publishers Ltd.

Abimbola, I. O. (2013). The Misunderstood Word In Science: Towards A Technology of Perfect Understanding for All. The One Hundred and Twenty Three (123rd) Inaugural Lecture. https://doi.org/http://www.unilorin.edu.ng/UIL/123.pdf

Ajayi, K., \& Ogunyemi, B. (1990). The relationship between instructional resources and socioeconomic status in selected population of high school. Dis. Abs. Int, 25(2), 22-23.

Ajegbelen, A. J. (2016). The use of ICT to enhance university education in Nigeria. International Journal of Education, Learning and Development, 4(5), 1-11. http://www.eajournals.org/wp-content/uploads/The-Use-of-ICT-to-Enhance-UniversityEducation-in-Nigeria..pdf

Alam, S. (2018). What do you understand by education technology and educational technology? Https://Www.Quora.Com/What-Do-You-Understand-by-EducationTechnolog y-and-Educational-Technology.

Amesi, J., \& Yellowe, I. T. (2018). Availability and utilization of information and communication technology gadgets in faculties of education in Rivers state universities, Nigeria. International Journal of Education and Evaluation, 4(4), 26-36. https://iiardpub.org/get/IJEE/VOL.\%204\%20NO.\%204\%202018/Availability\%20and\%20 Utilization.pdf

Applied Scholastic International. (2019). what is study technology? Http://Www.Appliedscholastics.Org/Study-Tech.Html.

Arrosagaray, M., González-Peiteado, M., Pino-Juste, M., \& Rodríguez-López, B. (2019). A comparative study of Spanish adult students' attitudes to ICT in classroom, blended and distance language learning modes. Computers and Education, 134(October 2018), 3140. https://doi.org/10.1016/j.compedu.2019.01.016

Augustine, N., Daud, S. M., \& Kamaruddin, N. S. (2018). Teachers use of ICT in teaching and learning in Aba North District secondary schools. Journal of Humanities and Social Science, $\quad 23(4), \quad$ 30-40. http://www.iosrjournals.org/iosrjhss/papers/Vol.\%2023\%20lssue4/Version-7/F2304073040.pdf

Bako, A. M. (2020). Lecturers' Preferences And Attitude Towards The Use Of Search Engines For Research In Universities In Bauchi State. Department of Educational Technology, Faculty of Education, University of Ilorin, Nigeria.

Church of Scientology international. (2019). the scientology handbook. In L. R. Hubbard. The Scientology Handbook, 2-10. http://www.scientologyhandbook.org/

Fernández-Gutiérrez, M., Gimenez, G., \& Calero, J. (2020). Is the use of ICT in education leading to higher student outcomes? Analysis from the Spanish Autonomous $\begin{array}{llll}\text { Communities. Computers and Education, 157, } 103969 . & \text { C }\end{array}$ https://doi.org/10.1016/j.compedu.2020.103969

Fritzenschaft, T. (2014). Critical sucess factors of change management. Springer Fachmedien.

Gambari, A. I., \& Yusuf, M. O. (2014). Development and Validation of Computer Instructional Package on Physics for Secondary Schools in Nigeria. Educational Research International, 2(1), 201-214. http://www.erint.savap.org.pk/PDF/Vol.3(1)/ERInt.2014(3.1- 
10).pdf

Hubbard, L. R. (1972). Ethics and Study Tech, Hubbard Communications Office Policy Letters.

Issa, A. I., Daramola, F. O., Aladesusi, G. A., \& Udoh, M. G. (2017). Assessment of undergraduate attitude to and utilization of mobile technologies for learning in Lagos state. Conference Proceedings Association of Innovative Technology in Education (AITIE 2017), 45-52.

Justina, E. I., Faben, M., \& Michael, S. G. (2018). Adequacy and utilization of ICT resources for quality instructional delivery in business education in universities in South-West Nigeria. International Journal of Innovative Information Systems \& Technology Research, 6(1), 28-37. https://seahipaj.org/journals-ci/mar-2018/IJIISTR/full/IJIISTR-M-4-2018.pdf

King, J. (2016). Advancing Educational Technology in Teacher Preparation. Policy Brief. U.S. Department of Education.

Lake, S. (2003). Barriers to study. Saint Louis, MO 63138 but Printed in the United States: Applied Scholastic International, 11755 Riverview Drive.

Lavanya, J., \& Santharooban, S. (2018). Usage of Online Resources by the Undergraduates Attached to the Faculty of Agriculture, Eastern University, Sri Lanka. Journal of the University Librarians Association of Sri Lanka, 21(2). https://doi.org/10.4038/jula.v21i2.7919

Mathew, D., Joro, I. D., \& Manasseh, H. (2015). The role of information and communication technology in Nigerian educational system. International Journal of Research in Humanities and Social Studies, 2(2), 64-68. http://www.ijrhss.org/pdf/v2-i2/8.pdf

Ndong, J. (2007). in Church of Scientology International (2007). Education-The Fatal Flaw. http://www.scientology.org

Newman, N. (2019). Journalism, Media and Technology Trends and Predictions 2019. In Business of Journalism Digital Media Online Journalism News Media. https://reutersinstitute.politics.ox.ac.uk/ourresearch/journalism-media-and-technology trends -and-predictions-2019

Okenjom, P. G., Ogar, E. C., Bake, K. O., \& Eze-Anyim, U. E. (2016). Technology Education Needs For Teachers in Nigerian Secondary Schools: The Role of the Library. Journal of Research \& Method in Education (IOSR-JRME), 6(2), 94-99. http://www.iosrjournals.org/iosr-jrme/papers/Vol-6\%20lssue-2/Version-1/P06020194 99.pdf

Oladipo, S., Olowoye, B., \& Adenaike, A. (2010). Comparative Study Of The Effect Of Study Technology Mode Of Instruction And Lecture Method On The Academic Performance Of University Students In Nigeria: Implication For Academic Staff Capacity Development. Academic Leadership: The Online Journal, 8(2). https://scholars.fhsu.edu/alj/vol8/iss2/13

Olumorin, C. O. (2009). Preparation/Production and Use of Visualization \& Non Visual/Instructional Materials \& Media for Teaching and Learning. Paper Presented at Adebola College 2 Day Capacity Building Seminar for Secondary School Teachers.

Onojah, A. O., Abimbola, I. O., Obielodan, O. O., Olumorin, C. O., Aderogba, A. J., \& Adeyanju, C. (2019). Undergraduate Student's Readiness Toward The Adoption of Study Technology for Learning in Kwara State, Nigeria. Indonesian Journal of Education and Research IJER, 4(2), 68-73. http://ijer.ftk.uinjambi.ac.id/index.php/ijer/article/view/124

Onuoha, U. D., \& Subair, M. O. (2013). Study habits of undergraduate students in selected federal universities in South-west Nigeria. International Research Journal, 4(10), 717721. https://doi.org/10.14303/er.2013.088

Owolabi, H. O. (2016). Educational research design. In H. O. Owolabi, The Concept of Research. INDEMIC Publisher. 
Sanni, T. A., Amosa, A. A., \& Danmaigoro, H. (2017). Technology education students' use of web-based instruction for learning: A case study of University of Ilorin, Nigeria. Conference Proceedings Association for Innovative Technology in Education (AITIE 2017), 231-328.

Soetan, A. K., Onojah, A. O., Alli, S. O., Aladesusi, G. A., Aderogba, A. J., \& Obielodan, O. O. (2020). Secondary School Teachers Utilization of Indigenous Instructional Resources in Teaching Basic Technology in Kwara State. EPIPHANY Journal of Transdisciplinary Studies, 13(1), 63-74. https://doi.org/10.21533/epiphany.v13i1.318.g209 